\title{
The End of Umpire?: Federalism and Judicial Restraint
}

Bruce Ryder

Osgoode Hall Law School of York University, bryder@osgoode.yorku.ca

Follow this and additional works at: https:// digitalcommons.osgoode.yorku.ca/sclr

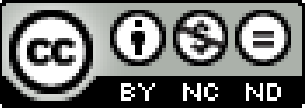

This work is licensed under a Creative Commons Attribution-Noncommercial-No Derivative Works 4.0 License.

\section{Citation Information}

Ryder, Bruce. "The End of Umpire?: Federalism and Judicial Restraint." The Supreme Court Law Review: Osgoode's Annual Constitutional Cases Conference 34. (2006).

https://digitalcommons.osgoode.yorku.ca/sclr/vol34/iss1/12 


\title{
The End of Umpire? Federalism and Judicial Restraint
}

\author{
Bruce Ryder*
}

\section{THE TURN TO JUDICIAL RESTRAINT}

The Supreme Court of Canada released eight decisions in 2005 that dealt with challenges to the validity of legislation based on the division of powers in sections 91 and 92 of the Constitution Act, 1867. ${ }^{1}$ Not since 1983, before Canadian Charter of Rights and Freedoms ${ }^{2}$ cases dominated its constitutional docket, has the Court decided so many federalism cases in a single year.

In the 2005 decisions, the judges were united around an approach to federalism disputes that the Court has consolidated over the past 15 years. With the exception of a lone justice in one case, ${ }^{3}$ in 2005 the Court was unanimous in affirming the validity and operation of the eight statutes challenged on division of powers grounds. A consistent posture of judicial restraint - or generous interpretations of the scope of both provincial and federal legislative jurisdiction — has been the defining feature of the Court's recent federalism jurisprudence.

The consensus on the current Court that declarations of ultra vires on federalism grounds should be issued rarely — with "extreme caution" in Patrick Monahan's words ${ }^{4}$ — has been developing for two

Associate Professor, Osgoode Hall Law School, York University.

(U.K.), 30 \& 31 Vict. c. 3, reprinted in R.S.C. 1985, App. II, No. 5.

Part I of the Constitution Act, 1982, being Schedule B to the Canada Act 1982 (U.K.), 1982, c. 11.

Castillo v. Castillo, [2005] S.C.J. No. 68, [2005] 3 S.C.R. 870, Bastarache J. concurring.

Patrick Monahan, "The Supreme Court of Canada and Canadian Federalism, 19962001" in P. Thibault, B. Pelletier \& L. Perret, eds., Les mélanges Gérald-A. Beaudoin: Les défis du constitutionnalisme 353 (Cowansville, Que.: Éditions Yvon Blais, 2002). Monahan concludes his study by observing that “... the current Court regards federalism as a political arrangement designed to facilitate the achievement by provincial majorities of collective goals. This suggests an attitude of extreme caution on the part of the current Court before it rules provincial legislation invalid." Id., at 366. I would add that this attitude of extreme caution is even more evident in the challenges to federal statutes that reach the Court. Together with the Court's expansion of the paramountcy rule, and its increased resort to the interjurisdictional immunity doctrine to restrict the operation of provincial statutes, the Court appears even more concerned with facilitating the achievement of collective goals by the federal government. 
decades. The Lamer Court was not shy about developing separation of powers doctrine ${ }^{5}$ or unwritten constitutional principles ${ }^{6}$ to place novel limits on the exercise of government power. But when it came to the division of powers, the Lamer Court exercised its power of judicial review in the direction of upholding challenged statutes, whether provincial or federal. The McLachlin Court, emphatically and usually unanimously, has continued this trend.

Can anyone remember the last time the Court declared a statute ultra vires as an invasion of the other level of government's exclusive jurisdiction in section 91 or 92 ? The last time a provincial law was declared invalid on federalism grounds was in the 1993 Morgentaler case $^{7}$ when Nova Scotia abortion regulations were found to be an invasion of the federal criminal law power. As for federal statutes, apart from an inconsequential provision of the proposed Civil Marriage Act that the Court said would be ultra vires in the Same-Sex Marriage Reference, ${ }^{8}$ one has to go back more than two decades, to the early 1980 s, to find the Court declaring a federal statute ultra vires on division of powers grounds. ${ }^{9}$ In short, when adjudicating federalism disputes, the Lamer and McLachlin Courts have followed the path of

5 E.g., Reference re Remuneration of Judges of the Provincial Court of Prince Edward Island, [1997] S.C.J. No. 75, [1997] 3 S.C.R. 3 [hereinafter "Provincial Judges Reference"]; MacMillan Bloedel Ltd. v. Simpson, [1996] S.C.J. No. 83, [1996] 2 S.C.R. 1048.

6 Provincial Judges Reference, id.; Reference re Secession of Quebec, [1998] S.C.J. No. 61, [1998] 2 S.C.R. 217 [hereinafter "Secession Reference"].

$7 \quad$ R. v. Morgentaler, [1993] S.C.J. No. 95, [1993] 3 S.C.R. 463. Of course, provincial statutes may be declared invalid for violating provisions of the Constitution Act, 1867 other than the division of powers. For example, in Re Eurig Estate, [1998] S.C.J. No. 72, [1998] 2 S.C.R. 565, a provincial regulation authorizing probate fees was found to be a valid exercise of provincial taxing powers pursuant to s. 92(2), but was invalidated on the grounds it was not authorized by the legislature as required by ss. 53 and 90 .

$8 \quad$ Reference re Same-Sex Marriage, [2004] S.C.J. No. 75, [2004] 3 S.C.R. 698 [hereinafter "Same-Sex Marriage Reference"]. The Court affirmed Parliament's ability to pass legislation defining marriage, for civil purposes, as the union of two persons to the exclusion of all others. The second provision of the Proposed Act, a declaratory provision stating that "[n]othing in the Act would affect the freedom of officials of religious groups to refuse to perform marriages that are not in accordance with their religious beliefs," was found to be in relation to the solemnization of marriage, a matter within provincial jurisdiction pursuant to s. 92(12) of the Constitution Act, 1867, and thus ultra vires Parliament. Id., at paras. 35-39.

9 See, e.g., Peel (Regional Municipality) v. Mackenzie, [1982] S.C.J. No. 58, [1982] 2 S.C.R. 9 (severing invalid portion of Criminal Code provision); Reference re Proposed Federal Tax on Exported Natural Gas, [1982] S.C.J. No. 52, [1982] 1 S.C.R. 1004 (part of proposed federal Bill ruled ultra vires). 
judicial restraint to a degree that is unprecedented in the Supreme Court's history. ${ }^{10}$

A great deal of Canadian constitutional scholarship takes for granted the importance and necessity of judges taking on the role of umpires of Canadian federalism. Without a neutral umpire to adjudicate disputes regarding the division of legislative powers, the argument goes, the constitution's commitment to the federal principle would not be secured. ${ }^{11}$ Others, like Paul Weiler, have argued that we would be better off if the courts did not enforce the constitutional division of powers at all (apart from asserting federal paramountcy where necessary) and simply left it to the politically accountable actors to determine the scope of their respective law-making powers. ${ }^{12}$ The Court's disinclination, since the early 1980s, to issue declarations of invalidity on division of powers grounds brings its current practices close to Weiler's views. The Court appears to be reaching the "end of umpire", preferring to leave the definition of jurisdictional boundaries to governments.

A closer look at the Court's federalism jurisprudence reveals a more complicated situation than simple judicial restraint in division of powers cases. The Court has almost entirely abandoned, for more than two decades, the use of declarations of ultra vires to police the division of powers. Over the same period, however, the Court has demonstrated an increased willingness to invoke the interjurisdictional immunity doctrine and the paramountcy doctrine to limit the application and operation of provincial statutes. These decidedly one-sided doctrines serve to limit

10 Patrick Monahan, in his study of the Court's federalism decisions from 1950 to 1984, found that the percentages of statutes challenged on federalism grounds held to be ultra vires ranged from a low of 20 per cent in the 1960s to over 40 per cent in the 1950s and from 1980-84. See Patrick Monahan, Politics and the Constitution: The Charter, Federalism and the Supreme Court of Canada (Toronto: Carswell, 1987) at 152. While I am not aware of any published data covering the entire post-1984 period since Monahan's study, it is clear that the percentage of challenged statutes held to be ultra vires on federalism grounds has plummeted since the early 1980s. See Monahan, supra, note 4, for an analysis of the case law from 1996 to 2001.

11 For an insightful discussion of the umpire metaphor as a description and ideal of the Court's role in federalism cases, see Donna Greschner, "The Supreme Court, Federalism and Metaphors of Moderation" (2001) 79 Can. Bar Rev. 47. Wayne MacKay has argued that the umpire metaphor obscures the political nature of constitutional decision-making and the creative role that the judges play in formulating the rules of federalism. See A. Wayne MacKay, "The Supreme Court and Federalism: Does/Should Anyone Care Anymore?" (2001) 80 Can. Bar Rev. 241.

12 Paul Weiler, In the Last Resort: A Critical Study of The Supreme Court of Canada (Toronto: Carswell/Methuen, 1974). In his provocative chapter entitled "The Umpire of Canadian Federalism", Weiler argued that "federalism cases involve essentially non-legal conflicts which will not be dealt with very successfully in the judicial process, and that courts should avoid the area unless their intervention is absolutely vital". Id., at 174 . 
provincial legislative powers, but have no impact on federal legislative powers. The Court's recent record in federalism disputes is thus a mix of judicial restraint and activism: restraint regarding declarations of invalidity, and activism when it comes to reading down or suspending provincial statutes.

\section{THE SUPREME COURT's THEORY OF FEDERALISM}

The Court's federalism decisions in 2005 involved a range of important federal and provincial laws. For the first time, the Court upheld the validity of the federal Trade-marks Act, and its "passing off" civil remedy, relying on an expansive interpretation of the trade and commerce power. ${ }^{13}$ Reversing the Quebec Court of Appeal, it found that the maternity and parental leave provisions of the federal Employment Insurance Act fell within a large and progressive interpretation of the federal power to make laws in relation to unemployment insurance. ${ }^{14}$ The Court was equally generous in its interpretation of the scope of provincial jurisdiction. It gave effect to Saskatchewan's prohibition on retail displays of tobacco products, ${ }^{15}$ applied Quebec labour statutes to a bankrupt employer, ${ }^{16}$ upheld the ability of a Quebec marketing statute to regulate the production of chickens destined for sale outside of the province,${ }^{17}$ affirmed Quebec's ability to regulate the colour of imported margarine sold in the province, ${ }^{18}$ suggested in obiter dicta that an Alberta limitations statute could apply to civil actions arising in foreign jurisdictions, ${ }^{19}$ and upheld British Columbia's novel legislation altering

13 Kirkbi AG v. Ritvik Holdings Inc., [2005] S.C.J. No. 66, [2005] 3 S.C.R. 302 [hereinafter "Kirkbi"]. Trade-marks Act, R.S.C. 1985, c. T-13.

14 Reference re Employment Insurance Act (Can.), ss. 22 and 23, [2005] S.C.J. No. 57, [2005] 2 S.C.R. 669 [hereinafter "Employment Insurance Reference"].

15 Rothmans, Benson \& Hedges Inc. v. Saskatchewan, [2005] S.C.J. No. 1, [2005] 1 S.C.R. 188 [hereinafter "Rothmans"].

16 D.I.M.S. Construction Inc. (Trustee of) v. Quebec (Attorney General), [2005] S.C.J. No. 52, [2005] 2 S.C.R. 564.

17 Fédération des producteurs de volailles du Québec v. Pelland, [2005] S.C.J. No. 19, [2005] 1 S.C.R. 292 [hereinafter "Pelland"].

18 UL Canada Inc. v. Quebec (Attorney General), [2005] S.C.J. No. 11, [2005] 1 S.C.R. 143 [hereinafter "UL Canada"].

19 Castillo v. Castillo, supra, note 3. 
the rules of civil liability and civil procedure in actions against tobacco manufacturers. ${ }^{20}$

This unusually high number of decisions affords us ample sources - relatively rare in the Charter era - to discern the understanding of federalism that is animating the Supreme Court's decision-making. This task, however, is complicated by the Court's reticence in recent division of powers cases - in contrast to its celebrated opinions in the Patriation Reference ${ }^{21}$ and the Secession Reference $e^{22}$ - to discuss the nature of Canadian federalism at any length. Indeed, it sometimes appears that the Supreme Court's theory of federalism is that it has no theory.

The Court has found little need to recognize the distinctiveness of its approach or to express its views on such issues as the relative merits of centralization versus decentralization, unity versus diversity, or exclusivity versus concurrency. Indeed, Deschamps J., speaking on behalf of the Court in the Employment Insurance Reference, cast doubt on whether the Court could unite around a particular view of Canadian federalism. In an unusually candid and revealing passage, she wrote as follows:

To derive the evolution of constitutional powers from the structure of Canada is delicate, as what that structure is will often depend on a given court's view of what federalism is. What are regarded as the characteristic features of federalism may vary from one judge to another, and will be based on political rather than legal notions. The task of maintaining the balance between federal and provincial powers falls primarily to governments. If an issue comes before a court, the court must refer to the framers' description of the power in order to identify its essential components, and must be guided by the way in which courts have interpreted the power in the past. In this area, the meaning of the words used may be adapted to modern-day realities, in a manner consistent with the separation of powers of the executive, legislative and judicial branches. ${ }^{23}$

20 British Columbia v. Imperial Tobacco Canada Ltd., [2005] S.C.J. No. 50, [2005] 2 S.C.R. 473 [hereinafter "Imperial Tobacco"].

21 Reference re Resolution to Amend the Constitution, [1981] S.C.J. No. 58, [1981] 1 S.C.R. 753.

22 Supra, note 6.

23 Supra, note 14 , at para. 10. 
Justice Deschamps' description of the Court's role is fascinating. It seems to cast doubt on the ability of the judges to agree on a theory of federalism, and yet simultaneously puts forward important judicial ingredients of just such a theory. In the end, with all due respect, Deschamps J. takes too modest a view of the judicial role. As several generations of constitutional scholars have emphasized, the text ("the framers' description of the power") and precedents ("the way in which courts have interpreted the power in the past") do not determine results in particular cases. The characterization of the subject matter of laws, and their allocation to particular heads of power, are value-laden exercises that involve a degree of judicial choice. ${ }^{24}$ As a result, the Court inevitably plays a creative and significant role in the evolution of Canadian federalism. ${ }^{25}$ The Court's decisions are guided by the constitutional text and past precedents, to be sure, but ultimately the Court must also make value choices about how the constitutional division of powers should help give shape to the federation.

Justice Deschamps' remarks were the most perceptive and candid issued by the Court in its 2005 federalism decisions. More typically, the Court tends to eschew explicit normative or theoretical discussion in division of powers cases. But I would argue that an immanent theory of federalism resides within the Court's jurisprudence. The features of the Court's theory of federalism can be cobbled together from what the Court has said and done in division of powers cases. I would suggest that the following six propositions capture the essence of the Court's approach to the interpretation of the division of powers:

1. Judicial interpretation of the constitution is partly and unavoidably subjective. Care should be taken to ensure that subjective judicial views do not thwart laws enacted by democratically accountable legislatures. Democracy is promoted by generous and flexible interpretations of both federal and provincial legislative powers. The primary responsibility for the maintenance of an appropriate balance between federal and provincial powers lies with the politically accountable branches of government. ${ }^{26}$

24 See, e.g., Bora Laskin, "Tests for the Validity of Legislation: What's the Matter?" (1955) 11 U.T.L.J. 114; W.R. Lederman, "Classification of Laws and the British North America Act" in Continuing Canadian Constitutional Dilemmas 229 (Toronto: Butterworths, 1981); Peter W. Hogg, Constitutional Law of Canada, looseleaf (Toronto: Carswell, 1987), at chapter 15.5(g).

25 For a recent elaboration of this theme, see A. Wayne MacKay, supra, note 11.

26 Employment Insurance Reference, per Deschamps J., supra, note 14. 
2. A large measure of judicial restraint should be exercised before laws are declared ultra vires on division of powers grounds, especially where jurisdictional conflict is absent or where governments have worked together to forge a cooperative legislative solution. Legislation should be declared ultra vires only when the enacting legislature has exceeded the boundaries of its jurisdiction in a manner that blatantly disregards the jurisprudence. ${ }^{27}$

3. It is particularly important that the courts permit the growth of federal legislative power through broad and dynamic interpretations of federal heads of power. ${ }^{28}$

4. The growth of de facto areas of concurrent jurisdiction should be welcomed. Overlap and interaction of federal and provincial powers should be tolerated and even promoted as an inevitable aspect of a modern, federal state. ${ }^{29}$

5. Exclusive federal powers deserve greater protection from provincial incursion than exclusive provincial powers do from federal

27 Id. See also Pelland, supra, note 17.

28 The Court has not stated this proposition explicitly, but it is supported by its interpretive practices. The Court has issued generous interpretations of a number of federal heads of power, many of which pushed these powers beyond their traditional parameters. See, for example, the Employment Insurance Reference, supra, note 14, regarding the unemployment insurance power in s. 91(2A); the Same-Sex Marriage Reference, supra, note 8, regarding the marriage power in s. 91(26); R. v. Crown Zellerbach Canada Ltd., [1988] S.C.J. No. 23, [1988] 1 S.C.R. 401 regarding the national concern branch of the peace, order and good government power; General Motors of Canada Ltd. v. City National Leasing Ltd., [1989] S.C.J. No. 28, [1989] 1 S.C.R. 641 and Kirkbi, supra, note 13, regarding the general regulation of trade branch of s. 91(2); and, perhaps most dramatically, RJR-MacDonald Inc. v. Canada (Attorney General), [1995] S.C.J. No. 68, [1995] 3 S.C.R. 199. R. v. Hydro-Québec, [1997] S.C.J. No. 76, [1997] 3 S.C.R. 213 and Reference re the Firearms Act (Can.), [2000] S.C.J. No. 31, [2000] 1 S.C.R. 783, regarding the criminal law power in s. 91(27). Assessing the latter three rulings, Peter Hogg has written that Parliament "can do much more with its criminal law power than we imagined 50 years ago, or even 10 years ago". Peter W. Hogg, "The Expansion of the Federal Power Over Criminal Law" in P. Thibault, B. Pelletier and L. Perret, eds., supra, note 4, 233 at 240. The Court's rulings have not resulted in similarly dramatic expansion of the scope of provincial heads of power. Jean Leclair has argued that the weight the Court accords to functional efficiency explains its tendency to strengthen the powers of the central government at the expense of regional diversity: see Jean Leclair, "The Supreme Court of Canada's Understanding of Federalism: Efficiency at the Expense of Diversity" (2003) 28 Queen's L.J. 411.

29 Ontario (Attorney General) v. OPSEU, [1987] S.C.J. No. 48, [1987] 2 S.C.R. 2, at 18. The tolerance of overlap and interplay between federal and provincial powers was evident in many of the 2005 decisions that upheld provincial or federal statutes despite their significant effects on subject matters within the other level of government's exclusive jurisdiction. See, e.g., Kirkbi, supra, note 13; Employment Insurance Reference, supra, note 14; Pelland, supra, note 17; UL Canada, supra, note 18; Imperial Tobacco, supra, note 20. 
incursion. The interjurisdictional immunity should be used to prevent provincial laws from applying to matters at the core of federal jurisdiction; no similar principle prevents federal laws from applying to matters at the core of provincial jurisdiction. ${ }^{30}$

6. The primacy of federal legislative policies must be protected by a broad interpretation of the federal paramountcy rule. ${ }^{31}$

The trend towards judicial restraint regarding declarations of ultra vires is a product of the Court giving effect to the first four postulates outlined above. The final two points give primacy to federal areas of jurisdiction or federal legislative policies, resulting in a trend towards increased judicial restriction of the permissible scope of application or operation of validly enacted provincial statutes.

In the balance of the paper, I will describe how the Court's approach to federalism cases outlined above was consolidated in its 2005 decisions. The Court gave expansive interpretations to federal powers (Part III below) and applied established interpretations of provincial powers in a flexible and generous manner (Part IV). It also confirmed its willingness to use the federal paramountcy rule to protect the primacy of federal legislative objectives (Part V). In the concluding section, Part VI, I will argue that the Court's theory of federalism is laudable from the point of view of the democratic principle, but has more contradictory and problematic implications that may pose a threat to the federal principle in the long run.

30 For applications of the interjurisdictional immunity doctrine to read down provincial statutes, see Ordon Estate v. Grail, [1998] S.C.J. No. 84, [1998] 3 S.C.R. 437; Commission de transport de la communauté urbaine de Québec v. Canada (National Battlefields Commission), [1990] S.C.J. No. 90, [1990] 2 S.C.R. 838; Bell Canada v. Quebec (Commission de la santé et de la sécurité du travail), [1988] S.C.J. No. 41, [1988] 1 S.C.R. 749. The Court has declined to apply the interjurisdictional immunity doctrine in a reciprocal manner to protect provincial heads of power from federal incursion. See, e.g., Friends of the Oldman River Society v. Canada (Minister of Transport), [1992] S.C.J. No. 1, [1992] 1 S.C.R. 3; Ontario Hydro v. Ontario (Labour Relations Board), [1993] S.C.J. No. 99, [1993] 3 S.C.R. 327; Alberta Government Telephones v. Canada (Canadian Radio-television and Telecommunications Commission), [1989] S.C.J. No. 84, [1989] 2 S.C.R. 225.

31 The Court has not stated this proposition explicitly, but it flows from its reasoning in Rothmans, supra, note 15, at paras. 11-14. See also Bank of Montreal v. Hall, [1990] S.C.J. No. 9, [1990] 1 S.C.R. 121, at 155; Law Society of British Columbia v. Mangat, [2001] S.C.J. No. 66, [2001] 3 S.C.R. 113, at paras. 69-70. 


\section{EXPANSIVE INTERPRETATION OF FEDERAL POWERS}

The Court upheld the two federal statutes that were challenged in 2005, and did so by broadly interpreting the federal legislative powers at stake.

\section{Employment Insurance Reference}

The Employment Insurance Reference ${ }^{32}$ was the one federalism case in 2005 in which a provincial government and the federal government clashed over a matter of jurisdiction. In conformity with a familiar pattern in Canadian federalism, the federal government prevailed in the courts, while Quebec's position was accommodated politically through intergovernmental negotiations.

At issue in the Employment Insurance Reference were the provisions of the federal Employment Insurance Act that confer maternity and parental benefits on eligible employees. The Quebec government initiated the reference after establishing its own Parental Insurance Plan in 2001, taking the position that the legislative provision of maternity and parental benefits falls within exclusive provincial jurisdiction pursuant to section 92(13) of the Constitution Act, 1867. In a unanimous ruling, the Quebec Court of Appeal agreed, striking down sections 22 and 23 of the Employment Insurance Act. The Supreme Court allowed the appeal, unanimously affirming the validity of the challenged federal provisions.

The competing approaches taken by the two Courts to the interpretation of the federal power to make laws in relation to unemployment insurance pursuant to section 91(2A) of the Constitution Act, 1867 make for a stark and fascinating contrast.

The Quebec Court of Appeal favoured a "mini-compact theory" that focused on the nature of the bargain made between the federal government and the provinces in 1940 when the Constitution was amended to give the federal government jurisdiction over unemployment insurance. For the Quebec Court of Appeal, the starting point was the protection of provincial jurisdiction over social policy: "these are measures which normally fall within provincial jurisdiction." ${ }^{33}$ In the Court's view, the degree of subtraction from

\footnotetext{
32 Supra, note 14.

33 Reference re Sections 22 and 23 of the Employment Insurance Act (Canada), [2004] J.Q. No. 277, 245 D.L.R. (4th) 515, at 527 (C.A.).
} 
provincial jurisdiction accomplished by the 1940 amendment should be limited strictly to the intent of the governments that negotiated that agreement. The Court thus accorded "primary importance" 34 to the evidence from the time suggesting that "unemployment insurance" was limited to an insurance scheme for earnings lost "for economic reasons" and not "for reasons based on personal circumstances" ${ }^{35}$ Reliance on the "living tree" metaphor would be inappropriate, the Court said, because it would constitute a betrayal of the agreement regarding the limited jurisdiction transferred by the provinces to the federal Parliament with the enactment of section 91(2A). In the Court's view, expansion of federal powers should take place only with provincial consent through the constitutional amending procedure. In conclusion, the Court wrote,

... the sections constitute an encroachment by the Canadian Parliament into a field which is reserved for the provinces, whereas no constitutional amendment has been enacted since 1940 which allows this. In the absence of any such amendment, I cannot see how one can set aside the consensus which was reached in order to add s. 91(2A) to the Constitution Act, 1867, a consensus which was based upon a highly restricted definition of the expression employment insurance. ${ }^{36}$

In allowing the appeal, and affirming the validity of the challenged provisions, the Supreme Court rejected the "mini-compact theory" adopted by the Quebec Court of Appeal. The starting point for the Supreme Court was not the preservation of provincial jurisdiction over social programs, or a strict interpretation of the 1940 amendment, but a generous and dynamic interpretation of federal power. Justice Deschamps, writing for a unanimous Court, chastised the Quebec Court of Appeal for placing such great weight on historical evidence of "original intent". While debates at the time are relevant, they cannot be treated as conclusive, Deschamps J. wrote, for the Court takes a progressive or dynamic approach to the interpretation of constitutional language. ${ }^{37}$

The same type of contest - between original intent and the need to update constitutional powers to meet changing social meanings and

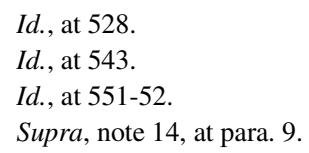


needs - arose in the Same-Sex Marriage Reference. ${ }^{38}$ Just as the Attorney General of Quebec in the Employment Insurance Reference argued that "unemployment insurance" had a fixed meaning, some intervenors argued that the meaning of marriage was fixed according to historical understandings limiting it to opposite-sex unions. The Court disagreed:

The "frozen concepts" reasoning runs contrary to one of the most fundamental principles of Canadian constitutional interpretation: that our Constitution is a living tree which, by way of progressive interpretation, accommodates and addresses the realities of modern life. ... A large and liberal, or progressive, interpretation ensures the continued relevance and, indeed, legitimacy of Canada's constituting document. By way of progressive interpretation our Constitution succeeds in its ambitious enterprise, that of structuring the exercise of power by the organs of the state in times vastly different from those in which it was crafted. ${ }^{39}$

Once the words of the Constitution are unhinged from original intent, and their meaning is freed to change with the times, the Court must face the formidable challenge of developing a methodology for ascertaining the limits of any particular federal or provincial head of power. In an impressive discussion that makes a considerable contribution to the jurisprudence, Deschamps J. confronted this difficult problem head on. Quoting Henri Brun and Guy Tremblay, she argued that the "essential elements" of a head of power can be identified by reference to the text and original intent, and then, within the confines of those essential elements, a generous and progressive interpretation can be guided by evolving social needs. ${ }^{40}$

Applying this approach, Deschamps J. concluded that the essential elements of unemployment insurance are that it is a public insurance plan aimed at preserving economic security by paying temporary income replacement benefits in the event of an interruption of employment. ${ }^{41}$ As labour market conditions evolve, so may the scope of

Supra, note 8.

39 Id., at paras. 22-23.

40 Employment Insurance Reference, supra, note 14, at paras. 36, 44-46 and 76. There is a great deal of judicial discretion in the identification of essential elements and evolving social needs, to be sure. But one cannot banish elements of subjectivity from any approach to constitutional interpretation. Justice Deschamps' approach provides a principled structure to the process of dynamic interpretation.

$41 \quad$ Id., at para. 48. 
federal jurisdiction. She then undertook a historical review of changes in the nature of employment, including women's increased participation in the labour force since 1940. She concluded that the maternity and parental benefits at issue are, in pith and substance, a mechanism for providing replacement income when employment is interrupted that respond to contemporary workplace realities. Thus, they fall within the essential elements of the federal power.

Justice Deschamps' powerful ruling results in Parliament and the provincial legislatures having overlapping jurisdiction to make laws in relation to maternity and parental benefits, Parliament pursuant to section 91(2A), and the provincial legislatures pursuant to section 92(13). Justice Deschamps commented that "[t]he power of one level of government to legislate in relation to one aspect of a matter takes nothing away from the power of the other level to control another aspect within its own jurisdiction." ${ }^{42}$ But is concurrency really just a win-win situation? Can we be so sanguine about the effects of shared jurisdiction on the federal principle?

The de facto concurrency that results from overlapping legislative powers has the potential advantage of permitting the expression of democratic will by either or both levels of government. This democratic advantage, however, comes at some risk to the federal principle. As discussed in Part V below, the Court has expanded its definition of the circumstances that give rise to federal paramountcy, thus making it possible for the federal Parliament to choose to block the operation of provincial laws in areas of shared jurisdiction. Moreover, even if Parliament chooses not to assert the primacy of its legislative policies, the passage of federal legislation may have the effect of ousting provincial jurisdiction as a matter of practical political realities. For example, the Quebec government's ability to pursue a distinct maternity and parental benefits program would have been severely limited if the federal government had insisted that the federal program must operate equally in Quebec, as it could have following the Court's ruling in the Employment Insurance Reference. The jurisprudence empowers Parliament to transform areas of concurrent jurisdiction into areas of $d e$ facto federal exclusivity. Thus, while Deschamps J.'s generous and dynamic interpretation of federal power advances the democratic principle by giving federal and provincial legislatures alike the 
flexibility to respond to new social needs, its implications for the federal principle are more problematic.

The Employment Insurance Reference affirmed the legal capacity of the federal Parliament to legislate a national scheme of maternity and parental benefits. Provincial governments interested in pursuing distinct policies could do so only if they succeeded in persuading the federal government to move aside in the name of provincial autonomy. Fortunately, from the point of view of the federal principle, Quebec has sufficient political power to extract concessions from the federal government in areas of shared jurisdiction, concessions that can then operate to the advantage of other interested provinces. In the period between the Quebec Court of Appeal and Supreme Court rulings, the Quebec and federal governments concluded an agreement whereby Quebec will operate its own Parental Insurance Plan which will provide maternity and parental benefits to Quebec claimants in lieu of the similar benefits in the Employment Insurance Act. ${ }^{43}$ Despite the legal potential for federal dominance created by the Court's ruling, the politics of Canadian federalism made room for the accommodation of Quebec's ability to pursue distinct social policies.

\section{Kirkbi AG v. Ritvik Holdings}

At issue in Kirkbi AG v. Ritvik Holdingss" (the "Lego v. MegaBloks case") was the constitutional validity of the "passing off" action in section 7(b) of the Trade-marks Act. In upholding section 7(b) as a valid exercise of federal jurisdiction pursuant to the "general regulation of trade" branch of the trade and commerce power in section 91(2) of the Constitution Act, 1867, the Court did not purport to expand the scope of federal jurisdiction. Rather, it simply applied the principles set out in

\footnotetext{
43 To enable the legislative implementation of the agreement with Quebec, in 2005 Parliament added s. 23(3.5) to the Employment Insurance Act, providing that federal parental benefits will be reduced or eliminated where "benefits are payable to a claimant ... for the same reasons under a provincial law ...". S.C. 1996, c. 23, s. 23, as amended by S.C. 2005, c. 30, s. 130. The Act already included a similar provision — s. 22(3) — permitting distinct provincial approaches to the provision of maternity benefits.

$44 \quad$ Supra, note 13. I should acknowledge that I appeared as counsel for the respondent Ritvik Holdings (Mega Bloks), unsuccessfully arguing against the constitutional validity of s. 7(b) of the Trade-marks Act. The reader may be justified in dismissing the comments that follow as sour
} grapes. 
General Motors of Canada v. City National Leasing ${ }^{45}$ the only other case in the modern era to result in legislation being upheld pursuant to the general regulation of trade power. However, the Court's approach to the potential breadth of the general regulation of trade power was far less cautious in 2005 than it was in 1989. The Court in Kirkbi was cavalier in authorizing overlapping federal legislation regarding local trade and the creation of civil causes of action, matters that according to section 92(13) fall within exclusive provincial jurisdiction. Thus, beneath the surface appearance of simple fidelity to precedent, the Kirkbi ruling is as strong an indication of the Court's willingness to interpret federal powers expansively as the more candid reasoning in the Employment Insurance Reference and the Same-Sex Marriage Reference.

Chief Justice Dickson in the General Motors case established five criteria to guide the determination of whether federal legislation that regulates local trade may nevertheless, in pith and substance, be in relation to the general regulation of trade: (i) the impugned legislation must be part of a regulatory scheme; (ii) the scheme must be monitored by the continuing oversight of a regulatory agency; (iii) the legislation must be concerned with trade as a whole rather than with a particular industry; (iv) the legislation should be of a nature that provinces jointly or severally would be constitutionally incapable of enacting; and (v) the failure to include one or more provinces or localities in a legislative scheme would jeopardize the successful operation of the scheme in other parts of the country. ${ }^{46}$ In General Motors, the Court had no difficulty concluding that the Combines Investigation Act (now the Competition Act) satisfied these criteria and thus was a valid exercise of federal jurisdiction. Similarly, LeBel $\mathrm{J}$. found it evident that the Trade-marks Act, the constitutional validity of which had not previously been affirmed, also satisfied the criteria for a valid exercise of the general regulation of trade power. ${ }^{47}$

More controversial was whether section 7(b) could also be held to be constitutionally valid because of a sufficiently strong connection to the regulatory scheme in the Trade-marks Act as a whole. Looked at in isolation, section $7(b)$ is clearly unconstitutional. Section $7(b)$ codifies

\footnotetext{
45 [1989] S.C.J. No. 28, [1989] 1 S.C.R. 641

46 Id., at 662-63, as summarized by LeBel J. in Kirkbi, supra, note 13, at para. 17.

47 Supra, note 13, at paras. 28-31.
} 
common law and civil law principles of liability and extends them on a national basis. It creates a statutory civil action that can be pursued in the Federal Court for losses resulting from a person directing "public attention to his wares, services or business in such a way as to cause or be likely to cause confusion in Canada ... with the wares, services or business of another". ${ }^{48}$ The creation of civil actions is a matter within exclusive provincial jurisdiction pursuant to section 92(13) of the Constitution Act, 1867. As the Court stated in General Motors, and reiterated in Kirkbi, "this provincial power over civil rights is a significant power and one that is not lightly encroached upon". ${ }^{49}$ The question, then, was whether section $7(b)$ is closely connected to a public scheme of national economic regulation, or whether it creates a freestanding national private tort action in violation of exclusive provincial jurisdiction.

This question was much easier to answer regarding the civil remedy at issue in General Motors. The civil action in the Combines Investigation Act supplemented public mechanisms of oversight and enforcement. Chief Justice Dickson's judgment devotes a great deal of attention to the presence of a scheme of public regulation operating under the oversight of a regulatory agency, and the enlistment of private enforcement through civil causes of action as an ancillary aspect of the scheme.

In contrast, the pith and substance of the scheme of regulation in the Trade-marks Act, operating under the oversight of the Registrar of Trade-marks, is the maintenance and operation of a trade-mark registry, and the ensuing efficient enforcement of registered trade-mark rights on a national basis through an infringement action. Section $7(b)$ has no significance for the holders of registered trade-marks; it is redundant in the face of the more powerful infringement action available to them. The significance of section $7(b)$ is that it permits the holders of unregistered trade-marks, defined by common law and civil law rules falling within exclusive provincial jurisdiction, to bring passing-off actions in Federal Court that could lead to the issuance of a remedy enforceable on a national basis. Apart from section 7, unregistered trade-marks are not protected by the regulatory scheme; the oversight of the Registrar of Trade-marks does not relate to them. In short, section

48 Trade-marks Act, R.S.C. 1985, c. T-13, s. 7(b).

49 General Motors, supra, note 45, at 672-73; Kirkbi, supra, note 13, at para. 23. 
7(b) does not appear to have any connection to a public scheme of national economic regulation.

It was for this reason that another provision of the same section was declared invalid by the Court in MacDonald v. Vapor Canada Ltd..$^{50}$ The Court held that section 7(e) constituted an invasion of exclusive provincial jurisdiction in relation to property and civil rights, and had no connection to the regulatory scheme set out in the Trade-marks Act. As Laskin C.J. wrote for the majority:

One looks in vain for any regulatory scheme in s. 7, let alone s. 7(e). Its enforcement is left to the chance of private redress without public monitoring by the continuing oversight of a regulatory agency which would at least lend some colour to the alleged national or Canada-wide sweep of s. 7(e). ... Even on the footing of being concerned with practices in the conduct of trade, its private enforcement by civil action gives it a local cast because it is as applicable in its terms to local or intraprovincial competitors as it is to competitors in interprovincial trade. ${ }^{51}$

The absence of regulatory oversight, or of any connection to a public scheme of national economic regulation, is equally true regarding section 7(b). The only difference is that, unlike section 7(e), section 7(b) shares with the rest of the Act the subject matter of trade-marks and the policy of protecting the holders of trade-marks from others trading on their goodwill through the use of confusing marks. But this shared subject matter and policy should not be constitutionally significant. After all, trade-marks, unlike patents and copyrights, are not a federal head of power. The Trade-marks Act is valid only because it consists, in pith and substance, of a public scheme of national economic regulation that differentiates it from regulation of local trade and the creation of civil causes of action. Otherwise, federal regulation of trade-marks would not be lifted out of provincial jurisdiction in relation to "property and civil rights" and into federal jurisdiction over the general regulation of trade. To be valid, therefore, section $7(b)$ has to be closely connected to that public scheme of regulation, not to the subject matter or policy of trade-marks writ large. The definition and protection of unregistered 
trade-mark rights remains a matter of exclusive provincial jurisdiction pursuant to section $92(13) .^{52}$

Furthermore, the civil action in General Motors was limited by its terms to the enforcement of the public prohibitions in the Combines Investigation Act. In other words, it was a new federal statutory tort. In contrast, section $7(b)$ is a simple codification and extension on a national basis of well-established common law and civil law principles of tortious responsibility. In this light, LeBel J.'s conclusions that section $7(b)$ is "limited in its application" and represents a minimal intrusion on exclusive provincial jurisdiction are hard to understand..$^{53}$

Section 7(b) does not make any reference to trade-marks or to other provisions of the Trade-marks Act. When LeBel J. comments that the purpose of section 7(b) "is to enforce the substantive aspects of the Trade-marks Act relating to unregistered trade-marks", ${ }^{54}$ he is engaged in an unspecified degree of "reading down" of the general language of the provision and finding connections with the rest of the Act that are at best obscure. ${ }^{55}$

In short, the Court's analysis leading to the upholding of section $7(b)$ pursuant to the general regulation of trade power was remarkably

52 See Hugues Richard, "De la constitutionallité de l'alinéa 7(b) de la Loi sur les marques de commerce" (1988-89) 1 Les Cahiers de propriété intellectuelle 229, at 232 : "Une marque non enregistrée existe en vertu des dispositions du droit civil au Québec et de la common law dans les autres provinces. Sa naissance, sa subsistence et son extinction dépendent du droit provincial applicable dans chaque province. Quant à nous, une marque de commerce non enregistrée existe complètement à l'extérieur du SYSTÈME DE RÉGLEMENTATION établi par le Parlement dans l'exercice de sa competence à l'égard des marques de commerce."

53 Kirkbi, supra, note 13, at paras. 26 and 27.

$54 \quad I d$., at para. 25.

55 The lack of a strong connection between s. 7(b) and the trade-marks registration scheme that is the pith and substance of the Act is confirmed by the legislative history of s. 7. When Parliament originally enacted a trade-mark registration scheme in 1868 , the civil action in the federal statute could be invoked only to prevent the unauthorized use of registered trade-marks. With the passage of s. 11 of the Unfair Competition Act in 1932 (the precursor to the present s. 7 of the Trade-marks Act), Parliament enacted prohibitions that extended beyond the use of registered trade-marks for the first time. The legislative debates in 1932 make clear that Parliament's purpose in enacting s. 11 was not to bolster or otherwise support the existing regulatory scheme for registered trade-marks. Rather, relying principally on its assumed power to implement Canada's international treaties, Parliament's purpose was to create more general statutory prohibitions on unfair competition in accordance with Canada's obligations pursuant to Article 10 bis of the International Convention for the Protection of Industrial Property, as revised at The Hague in 1925. See House of Commons Debates (1932) at 11-12, 162, 2541-2; Senate Debates (1932) at 419. 
deferential to Parliament ${ }^{56}$ and suggests that the Court may be open to further expansion of federal jurisdiction over economic regulation in the future.

\section{EXPANSIVE INTERPRETATION OF PROVINCIAL POWERS}

In 2005, the Supreme Court rejected three challenges to the operation or application of valid provincial statutes, ${ }^{57}$ and upheld three provincial statutes from challenges to their validity on division of powers grounds. ${ }^{58}$ The Court's decisions upholding the validity of provincial statutes did not require the development of new legal doctrine or the bold expansion of provincial heads of power as we saw regarding federal powers in the Employment Insurance Reference and the Kirkbi case. The Court has generously interpreted provincial jurisdiction, but it has not been eloquent in its recent decisions about the importance of respecting provincial autonomy. The Court has simply interpreted wellestablished principles in a manner that has been favourable to provincial legislative jurisdiction. In particular, the Court has used the pith and substance doctrine and its corollary, the incidental effects doctrine, to uphold provincial statutes so long as they have had a strong connection to a matter within provincial jurisdiction. The fact that these statutes also had substantial impact on matters outside of jurisdiction was characterized as incidental, irrelevant for the purposes of constitutional validity.

\section{UL Canada v. Quebec}

For example, in UL Canada Inc. v. Quebec (Attorney General), ${ }^{59}$ at issue was the constitutional validity of a Quebec regulation prohibiting the sale of yellow margarine in the province. The regulation serves the interests of the dairy industry, which is anxious to protect butter from

\footnotetext{
56 No doubt part of the explanation for the Court's apparently casual treatment of the constitutional issue in Kirkbi was the lack of a jurisdictional conflict behind the constitutional argument. Indeed, the Quebec Attorney General was the only provincial Attorney General to intervene at the Supreme Court and it did so in support of the constitutional validity of s. 7(b).

57 Notes 15 to 17 , supra.

58 Notes 18 to 20, supra.

59 [2005] S.C.J. No. 11, [2005] 1 S.C.R. 143
} 
the spread of margarine. ${ }^{60}$ UL Canada, a subsidiary of Unilever, which controls more than one-half of the margarine market in Quebec, imported yellow margarine into Quebec with the purpose of initiating a legal challenge to the regulation. The Quebec courts upheld the validity of the regulation, as did the Supreme Court, dismissing the appeal in a short oral decision delivered at the hearing without having to hear Quebec's submissions. Justice LeBel, stating the opinion of the Court, dispensed with the division of powers' argument in two sentences:

The appellant [UL Canada] has not shown that this Court should intervene to reverse the judgments of the courts below. Based on the constitutional principles governing the division of legislative powers, the impugned regulatory provision is within the limits of the provinces' legislative authority over local trade. ${ }^{61}$

One wonders why the Court granted leave, and stated four constitutional questions, when it ended up having so little to say about the result. To find a more sustained description of the scope and importance of provincial jurisdiction in relation to local trade, one must turn to the reasons of the Quebec Court of Appeal ${ }^{62}$ (which presumably the Supreme Court agreed with, although LeBel J. did not say so explicitly).

UL had argued that the pith and substance of the regulation was in relation to international trade since it prevented foreign manufacturers of yellow margarine from selling their product in the province. UL was continuing a half-century-long constitutional struggle to legalize the sale of margarine in Canada. In the Margarine Reference, the Supreme Court held that a federal law prohibiting the manufacture and sale of margarine, which also had the purpose of protecting the dairy industry, was ultra vires. ${ }^{63}$ The regulation of the manufacture and sale of margarine fell within provincial jurisdiction. The Court upheld the validity of one provision of the federal law, the prohibition on the importation of margarine. The Quebec government responded to the Court's 1948 opinion by promptly passing its own law prohibiting the sale and manufacture of margarine in the province. The Quebec law

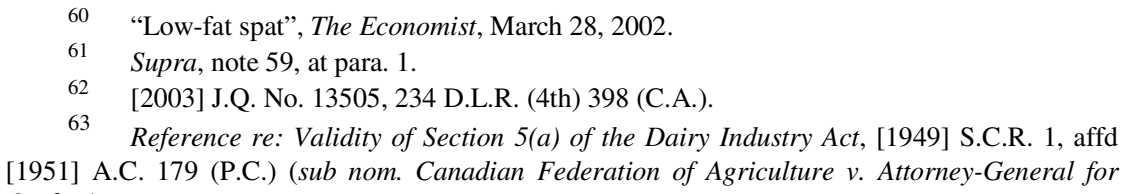


has since evolved into a prohibition only on margarine that looks like butter.

The Quebec regulation prohibiting the sale of yellow margarine at issue in UL Canada makes no distinction between imported and locally produced margarine. UL Canada argued that the regulation's impact on imported products constituted an invasion of federal jurisdiction in relation to international trade. Emboldened by Supreme Court decisions in the 1990s that gave decisive weight to the unwritten structural principles of the constitution, ${ }^{64}$ UL Canada also argued that the regulation violated the principle, allegedly inherent in the structure of federalism, that goods, regardless of colour, should be able to move freely across borders.

The Quebec Court of Appeal dismissed each of these arguments. Since the Court found that the legislative purpose of the regulation is to protect the Quebec dairy industry, rather than to restrict the sale of an imported product, the Court concluded that the regulation's pith and substance relates to local trade, a matter within provincial jurisdiction pursuant to section 92(13). Relying on Supreme Court decisions that had upheld provincial jurisdiction over marketing and consumer protection, ${ }^{65}$ and distinguishing those that did not ${ }^{66}$ the Court of Appeal found that the negative effects of the regulation that fall primarily on foreign manufacturers are "incidental" to the regulation's dominant purpose. $^{67}$

As for the argument that the free movement of goods across borders is a binding principle of the federal system, the Quebec Court of Appeal rejected this submission as "ill-founded". ${ }^{67 a}$ The Court noted that a common market runs counter to federalism's promotion of provincial autonomy and diversity, quoting Bastarache and Iacobucci JJ.'s opinion in Canadian Egg Marketing Agency v. Richardson to that effect:

64 Hunt v. T\&N plc, [1993] S.C.J. No. 125, [1993] 4 S.C.R. 289; Provincial Judges Reference, [1997] S.C.J. No. 75, [1997] 3 S.C.R. 3; Secession Reference, [1998] S.C.J. No. 61, [1998] 2 S.C.R. 217.

65 Quebec (Attorney General) v. Kellogg's Co. of Canada, [1978] S.C.J. No. 5, [1978] 2 S.C.R. 211; Carnation Co. v. Quebec (Agricultural Marketing Board), [1968] S.C.J. No. 11, [1968] S.C.R. 238.

66 Manitoba (Attorney General) v. Manitoba Egg and Poultry Assn., [1971] S.C.J. No. 63, [1971] S.C.R. 689; Burns Foods v. Manitoba (Attorney General), [1975] S.C.J. No. 151, [1975] 1 S.C.R. 494.

67 Supra, note 62, at 421-25.

67a Id., at 425 . 
The federal structure of our Constitution authorizes the growth of distinct systems of commercial regulation whose application is inevitably defined "in terms of provincial boundaries" ... This type of economic legislation, and the growth of divergent regulatory regimes in the provinces, is undoubtedly authorized by the Constitution. ${ }^{68}$

\section{British Columbia v. Imperial Tobacco Ltd.}

A similarly generous approach to provincial jurisdiction is evident in the Court's decision in British Columbia v. Imperial Tobacco Ltd. ${ }^{69}$ At issue was the constitutional validity of the British Columbia Tobacco Damages and Health Care Costs Recovery Act. ${ }^{70}$ The Act authorizes an action by the provincial government against manufacturers of tobacco products for the recovery of its health care expenditures caused by tobacco-related disease. The Act also alters the common law rules applicable in private tort actions to make it easier for plaintiffs to recover damages for tobacco-related injuries. A coalition of tobacco manufacturers challenged the constitutional validity of the statute on a number of grounds. They argued that the Act is outside the territorial limits on provincial powers because it targets companies mostly situate outside of the province and premised liability on exposure to tobacco products even if that exposure occurred outside of the province. The tobacco companies also argued that the Act should be declared invalid on the grounds that it violates the rule of law and judicial independence, two unwritten foundational norms of the Constitution to which the Court has attributed binding force.

Section 92(13) confers on the provinces exclusive jurisdiction to make laws in relation to "property and civil rights in the province". The creation of civil causes of action is a matter that falls within section 92(13). Since the Act deals with civil liability and civil procedure, it is clearly in relation to "property and civil rights". The more difficult issue is whether it can also be said that the Act is in relation to rights that are situate "in the province". At trial, Holmes J. thought not. He declared the Act ultra vires on the grounds that it exceeded the territorial limitations on provincial powers. Justice Holmes found the pith and substance of the Act to be the pursuit of the national and international

\footnotetext{
68 [1998] S.C.J. No. 78, [1998] 3 S.C.R. 157, at 198.

69 [2005] S.C.J. No. 50, [2005] 2 S.C.R. 473.

70 S.B.C. 2000 , c. 30
} 
tobacco industry to recover B.C.'s health care costs incurred as a result of people's exposure to tobacco products, wherever that exposure occurred. Given the national and international nature of the tobacco industry, and the substantial exposure B.C. residents have had to tobacco products outside of the province, Holmes J. concluded that the extraterritorial effects of the Act were "substantial"; they could not be treated as minor or incidental. ${ }^{71}$

In unanimous decisions, the B.C. Court of Appeal and Supreme Court of Canada disagreed, concluding that the extraterritorial effects of the legislation were incidental to its main purpose. Justice Major, writing a succinct and forceful unanimous opinion for the Supreme Court, stated that a civil cause of action will be "in the province" if it has a "meaningful connection" to the province and does not interfere with the legislative sovereignty of other jurisdictions. ${ }^{72}$ Because the cause of action that is the pith and substance of the Act relates to recovery of "expenditures incurred by the B.C. government for the health care of British Columbians", Major J. had no difficulty concluding that the Act had a meaningful connection to B.C. and did not intrude on legislative jurisdiction elsewhere. "[N]o territory", he wrote, "could possibly assert a stronger relationship to that cause of action than British Columbia." 73 As for the fact that the Act captures breaches of duty and exposure to tobacco products outside of the province, Major J. dismissed these extraterritorial effects of the Act as "subsidiary", "irrelevant to the Act's validity". ${ }^{74}$

Justice Major's opinion is a textbook example of the generous use of the pith and substance doctrine and ancillary effects doctrine to enable the creative deployment of provincial legislative jurisdiction in response to new social and economic circumstances. In Imperial Tobacco, it was not necessary to resort to the living tree metaphor to permit growth and expansion of provincial powers, as the Court did for federal powers in the Same-Sex Marriage Reference and the Employment Insurance Reference. But the effect of Major J.'s methodology is the same - constitutional flexibility in the service of democracy.

[2003] B.C.J. No. 1309, 227 D.L.R. (4th) 323, at 381 (S.C.).

Supra, note 69, at para. 36 .

Id., at para. 38 .

$I d$, at paras. $40-42$ 
The result in Imperial Tobacco was perhaps not surprising given the absence of any jurisdictional conflict behind the litigation. Other provinces are interested in passing similar legislation, and the Attorney General of Canada chose not to intervene. The Court's ruling evinces a healthy skepticism of attempts by private actors to use division of powers arguments - and unwritten constitutional principles ${ }^{75}-$ to avoid regulation contrary to their interests.

\section{Fédération des producteurs de volailles du Québec v. Pelland}

A similar skepticism characterized the Court's dismissal of the challenge to Quebec chicken marketing legislation in Fédération des producteurs de volailles du Québec v. Pelland. ${ }^{76}$ At issue was an interlocking federal-provincial marketing scheme for chickens that had been enacted following the agricultural products marketing "blueprint" 77 approved by the Supreme Court of Canada in the 1978 Egg Reference ${ }^{78}$ (in Canada, the answer to the question "which came first, the chicken or the egg case?", is clear).

Canadian governments have long sought to ensure a dependable supply of agricultural products for consumers and price support for producers through the enactment of marketing schemes. Divided jurisdiction over the regulation of trade has posed a challenge to the design of effective schemes. This challenge can be overcome through the enactment of interlocking federal and provincial legislation, coupled with the use of administrative delegation and referential incorporation, to give one body, in this case the Fédération des producteurs de volailles, complete jurisdiction over production and marketing.

Pelland, a Quebec farmer, produces chickens for sale in Ontario. He exceeded his quota imposed by the Fédération by almost 4.5 million kilograms. In response to legal action taken against him by the Fédération, he argued that the Quebec legislation could not apply to production destined solely for extraprovincial trade. The Quebec courts

75 As Major J. wrote, “... in a constitutional democracy such as ours, protection from legislation that some might view as unjust or unfair properly lies not in the amorphous underlying principles of our Constitution, but in its text and the ballot box." Id., at para. 66.

76 [2005] S.C.J. No. 19, [2005] 1 S.C.R. 292.

77 Id., at para. 2. S.C.R. 1198

Reference re Agricultural Products Marketing Act, [1978] S.C.J. No. 58, [1978] 2 
and the Supreme Court dismissed his argument. Justice Abella, writing for a unanimous Court, strongly supported a scheme that, in her words, "reflects and reifies Canadian federalism's constitutional creativity and cooperative flexibility". ${ }^{79}$ She gave two reasons for upholding the application of the Quebec legislation to Mr. Pelland.

First, liberally using the pith and substance doctrine as the Court did in UL Canada and Imperial Tobacco, she concluded that the pith and substance of the Quebec legislation was the regulation of agricultural production, a matter within provincial jurisdiction. In her view, the purpose of the Act was not the control of extraprovincial trade, and its effects on extraprovincial trade were incidental. ${ }^{80}$ Justice Abella emphasized that overlapping jurisdiction is inevitable and tolerable in a federal state, hence the need to focus on the core character of the impugned legislation to determine validity. It followed that the Quebec legislation could apply to Mr. Pelland's production of its own force, without any federal assistance.

Second, in any case, the federal delegation of jurisdiction over extraprovincial trade to the Fédération was valid and provided a further reason why Mr. Pelland must submit to the production quota imposed on him. Justice Abella's concluding comments are strongly supportive of the legal architecture of cooperative federalism put in place in 1978:

I see no principled basis for disentangling what has proven to be a successful federal-provincial merger. Because provincial governments lack jurisdiction over extraprovincial trade in agricultural products, Parliament authorized the creation of federal marketing boards and the delegation to provincial marketing boards of regulatory jurisdiction over interprovincial and export trade. Each level of government enacted laws and regulations, based on their respective legislative competencies, to create a unified and coherent regulatory scheme. The quota system is an attempt to maintain an equilibrium between supply and demand and attenuate the inherent instability of the markets. To achieve this balance, it cannot exempt producers who seek to avoid production control limits by devoting all or any of their production to extraprovincial trade. ${ }^{81}$

\footnotetext{
79 Supra, note 76, at para. 15.

$80 \quad$ Id., at para. 37.

$81 \quad$ Id., at para. 38.
} 


\section{EXPANDING APPROACH TO PARAMOUNTCY}

Given the Court's tendency to uphold challenged statutes by interpreting federal and provincial heads of power generously, thus permitting the growth of de facto areas of concurrent jurisdiction, it becomes increasingly important to the federal balance of powers for the Court to affirm a limited definition of conflict that gives rise to federal paramountcy. Paramountcy is the federal government's trump card. A broad definition of when it can be put in play stacks the deck of cooperative federalism too strongly in the direction of the federal government. ${ }^{82}$ It empowers Parliament to oust provincial legislatures' ability to pursue distinct policies in areas of overlapping jurisdiction. Unfortunately, during the same time period that the Court has practised "considerable circumspection" 83 when invited to use declarations of ultra vires to police the division of powers, it has adopted a broader definition of the kinds of conflict that will give rise to federal paramountcy. The result is the potential for the exclusive reign of federal legislative policy choices in areas of shared jurisdiction. The simultaneous expansion of concurrency and paramountcy poses a serious threat to the federal principle in Canada. It puts provincial autonomy at the mercy of federal forbearance.

\section{Rothmans, Benson \& Hedges Inc. v. Saskatchewan}

The Court's 2005 ruling on the paramountcy rule, Rothmans, Benson \& Hedges Inc. v. Saskatchewan, ${ }^{84}$ is a significant consolidation and restatement of the revised approach the Court has followed since 1990. There is no need to discuss the decision at any length here, as Peter Hogg has described its significance with his usual clarity in his contribution to this volume.$^{85}$ The essence of the Court's ruling is that it confirms that the narrow "impossibility of dual compliance" test for

\footnotetext{
82 Given the importance of protecting regional diversity in the Canadian context, the need for a narrow approach to the paramountcy rule is one point on which anglophone and francophone scholars tend to agree. See, e.g., David Beatty, Constitutional Law in Theory and Practice (Toronto: University of Toronto Press, 1995) at 46; Eugénie Brouillet, La Négation de la Nation: L'identité culturelle québécoise et le fédéralisme canadien (Septentrion: Sillery, Qué., 2005) at 270-75.

Employment Insurance Reference, [2005] S.C.J. No. 57, [2005] 2 S.C.R. 669, at para. 8.

84 [2005] S.C.J. No. 1, [2005] 1 S.C.R. 188.

85 Peter W. Hogg, "Paramountcy and Tobacco", in this volume.
} 
conflict $^{86}$ has been supplemented by, or absorbed into, a broader "frustration of the federal legislative purpose" test. ${ }^{87}$ In the words of Major J., writing for a unanimous Court in Rothmans,

... the overarching principle ... is that a provincial enactment must not frustrate the purpose of a federal enactment, whether by making it impossible to comply with the latter or by some other means. In this way, impossibility of dual compliance is sufficient but not the only test for inconsistency. ${ }^{88}$

When adopting the impossibility of dual compliance test in 1982, Dickson J. justified his choice by reference to the value of provincial autonomy. ${ }^{89}$ Now, the focus has shifted from protecting provincial autonomy to promoting the primacy of federal policy objectives. This is a significant normative shift, one that has been introduced by the Court with no discussion of the values that have driven its choice or of the consequences that might ensue. This is unfortunate, for as Zoe Oxaal puts it,

... no matter where one sits in debates on federalism, when changes to the balance of the federal system come about through incremental changes in the jurisprudence, then they ought to be closely scrutinized, just as we would scrutinize proposed constitutional amendments. Federalism is the blueprint of the Canadian constitutional structure, and interpretive shifts in its doctrines, such as federal paramountcy, have "profound implications ... for the balance of power in the federal system." "90

As Peter Hogg's paper discusses,${ }^{91}$ in Rothmans the Supreme Court concluded, reversing the Saskatchewan Court of Appeal, that Saskatchewan's legislation prohibiting retail displays of tobacco

86 The leading case espousing this approach is Multiple Access Ltd. v. McCutcheon, [1982] S.C.J. No. 66, [1982] 2 S.C.R. 161.

87 The frustration of the federal legislative purpose was first articulated by La Forest J. in Bank of Montreal v. Hall, [1990] S.C.J. No. 9, [1990] 1 S.C.R. 121 and subsequently applied in 114957 Canada Ltée (Spraytech, Société d'arrosage) v. Hudson (Town), [2001] S.C.J. No. 42, [2001] 2 S.C.R. 241, at para. 35, and Law Society of British Columbia v. Mangat, [2001] S.C.J. No. 66, [2001] 3 S.C.R. 113, at paras. 69-70.

88 Supra, note 84, at para. 14.

89 Multiple Access v. McCutcheon, supra, note 86, at 190.

90 Zoe Oxaal, "Cigarettes Behind Curtains: Federal Paramountcy and the Saskatchewan Court of Appeal: A Comment on Rothmans, Benson and Hedges v. Saskatchewan" (2004) 67 Sask. L. Rev. 401, at 411 .

91 Supra, note 85 . 
products did not frustrate Parliament's legislative purpose in permitting such displays. The provincial right to pursue distinct legislative policies reflecting local needs and desires thus prevailed in an area of shared jurisdiction. Nevertheless, the Court's approach does not augur well for the future of the federal principle.

If federal policy objectives are treated as supreme, the exercise of provincial autonomy in areas of shared jurisdiction is rendered entirely dependent upon the will of the federal Parliament. If one of Parliament's policy objectives is to oust provincial legislation entirely from an area of shared jurisdiction, then apparently all Parliament has to do is say so. In essence the definition of conflict adopted by the Court transfers control over the scope of the paramountcy rule from the judiciary to Parliament. Consider Major J.'s response to Rothmans' submission that Parliament intended to oust provincial legislation from the regulation of retail tobacco displays:

In my view, to impute to Parliament such an intention to "occup[y] the field" in the absence of very clear statutory language to that effect would be to stray from the path of judicial restraint in questions of paramountcy that this Court has taken ... ${ }^{92}$

With all due respect, the Court's focus on the primacy of federal legislative purposes is not the path of judicial restraint. Judicial restraint was the result in Rothmans, but only because of Parliamentary restraint. Parliament now decides whether overlapping provincial legislation can operate in areas of shared jurisdiction.

No doubt the result in Rothmans was influenced by the Attorney General's intervention arguing that Parliament's objective was not frustrated by the Saskatchewan law. As Major J. explained at the end of his opinion in Rothmans:

While the submissions of the federal government are obviously not determinative of the legal question of inconsistency, there is precedent from this Court for bearing in mind the other level of government's position in resolving federalism issues ... ${ }^{93}$

Would provincial autonomy have prevailed in Rothmans if the Attorney General of Canada had submitted that the Saskatchewan provisions did frustrate Parliament's legislative objective? It is difficult 
to say. We can say that it is increasingly important for provincial laws to be aligned with federal legislative policies if they are to operate in areas of overlapping jurisdiction. This is not good news for provincial autonomy.

\section{JUDICIAL RESTRAINT, DEMOCRACY AND FEDERALISM}

Judicial reluctance to issue rulings of ultra vires on federalism grounds, as we witnessed on the part of the Supreme Court in 2005 — indeed for the past two decades - has the laudable effect of maximizing the democratic space available to Parliament and the provincial legislatures. Especially in comparison to the anti-democratic tendencies of the "watertight compartments" paradigm favoured by the courts at times in the past,${ }^{94}$ the Court's commitment to giving both Parliament and the provincial legislatures the benefit of the doubt should be applauded. It leaves the resolution of federalism disputes primarily to intergovernmental negotiations between politically accountable officials. Because of these democratic advantages, and in light of the inherently subjective elements of judicial review, many leading constitutional scholars - among them Paul Weiler, ${ }^{95}$ Peter Hogg ${ }^{96}$ and David Beatty ${ }^{97}$ — have urged the Court to exercise restraint when determining whether Parliament or a provincial legislature has complied with the division of powers. These apostles of restraint ought to be pleased with the Court's apparent conversion to the cause.

94 The classical view of legislative heads of power as "watertight compartments" has antidemocratic tendencies because social problems deserving legislative responses rarely fit neatly within one level of government's areas of jurisdiction. Spillover effects on the other level of government's powers are inevitable. For a discussion, see Bruce Ryder, "The Demise and Rise of the Classical Paradigm in Canadian Federalism: Promoting Autonomy for the Provinces and the First Nations" (1991) 36 McGill L.J. 308.

95 Paul Weiler, In the Last Resort: A Critical Study of the Supreme Court of Canada (Toronto: Carswell/Methuen, 1974).

96 Peter Hogg, Constitutional Law of Canada, supra, note 24, chapter 5.5(b): “... the appropriate posture for the courts in distribution of powers (or federalism) cases is one of restraint: the legislative decision should be overridden only where its invalidity is clear."

97 David Beatty, Constitutional Law in Theory and Practice (Toronto: University of Toronto Press, 1995). Beatty describes the "essence of the federal principle" as the protection of "the autonomy and sovereignty of both levels of government as much as possible". Id., at 41-42. He applauds the liberal use of the pith and substance and ancillary doctrines: "Together [they] have strengthened the federal character of the constitution by enlarging the fields of social policy over which both levels of government have some authority to act." Id., at 46. 
It would be a mistake to think that the Court's role in shaping the law of federalism is only significant when it declares statutes invalid. Whatever results it reaches, the Court's decisions have an important influence on the scope of governments' powers and their respective bargaining positions in intergovernmental negotiations. Moreover, the restraint the Court has exercised regarding declarations of invalidity over the past two decades has been matched over the same period by an expansion of the test for conflict giving rise to federal paramountcy and increased resort to the interjurisdictional immunity doctrine to restrict the operation of provincial statutes. The combined effect of these trends has been to increase the legal potential for federal dominance and provincial subordination. ${ }^{98}$

Judicial restraint tends to expand areas of de facto concurrent power in which the legislative policy choices of Parliament are paramount. The federal principle holds that federal and provincial governments are coordinate (equal in status) and autonomous within their respective spheres of jurisdiction. ${ }^{99}$ Judicial interpretation that is faithful to the federal principle will thus give equal weight to the claims of federal and provincial autonomy.

Judicial restraint promotes the democratic principle by maximizing the powers of democratically elected legislatures but compromises the federal principle to the extent that it enlarges areas of concurrent power in which the provinces are subordinate to overriding federal jurisdiction. ${ }^{100}$ Because of the federal paramountcy rule, areas of concurrent jurisdiction are not ones in which the provinces are equal in status to the federal government. It has long been a theme of Québécois scholarship on the Constitution that concurrent jurisdiction risks producing provincial subordination rather than the equality of status that is the hallmark of the federal principle. ${ }^{101}$ Reflecting this concern, Beetz J. argued that provincial and federal jurisdiction should be kept "as far

98 For a detailed critique of the centralizing trends in the law of federalism, see Eugénie Brouillet, La Négation de la Nation: L'identité culturelle québécoise et le fédéralisme canadien (Septentrion: Sillery, Que., 2005).

99 This is a widely accepted definition. See, e.g., Hogg, supra, note 96, chapter 5.1(a), quoting K.C. Wheare, Federal Government (4th ed. 1963) at 10.

100 Beatty (supra, note 97 ) can be accused of too readily equating the democratic principle with the federal principle. Enlarging the spheres in which both levels of government can act, coupled with a broad approach to federal paramountcy, risks compromising the federal principle.

101 For an overview, see Ryder, supra, note 94, at 341-346, 351-359. 
as possible in separate areas"102 to limit the "risk that these two fields of exclusive powers will be combined into a single more or less concurrent field of powers governed solely by the rule of paramountcy of federal legislation. Nothing could be more directly contrary to the principle of federalism underlying the Canadian Constitution." ${ }^{103}$ As Henri Brun and Eugénie Brouillet have argued, in areas of concurrent jurisdiction the provinces are in a constitutionally precarious position, "à la merci de la volonté fédérale". ${ }^{104}$

In an era of judicial restraint, then, provincial legislative autonomy is rendered increasingly dependent upon securing federal consent - or, at least, federal forbearance. The provinces have only a conditional autonomy within areas of de jure or de facto concurrent jurisdiction. Rather than exercising guaranteed, exclusive jurisdiction, they are put in the position of supplicants to the federal government. To secure legislative space for the pursuit of distinct policy objectives, the provinces must negotiate with a national government that is holding the legal trump card - the federal paramountcy rule — in its hand.

Judicial restraint thus casts the primary responsibility for securing the equal sovereignty of federal and provincial governments onto the political sphere of intergovernmental negotiations. The degree of respect accorded to the federal principle will depend on the vagaries of intergovernmental politics. Fortunately, from the point of view of the federal principle, the potential for federal dominance embedded in the law of federalism has been curtailed by the strong centrifugal forces in Canadian politics. As K.C. Wheare succinctly put it, the quasi-federal elements of Canadian constitutional law are circumscribed by the

102 Bell Canada v. Quebec (Commission de la Santé et de la sécurité du travail), [1988] S.C.J. No. 41, [1988] 1 S.C.R. 749, at 844.

103 Id., at 766. See also William Lederman, "The Balanced Interpretation of the Federal Distribution of Legislative Powers in Canada" in Continuing Canadian Constitutional Dilemmas (Toronto: Butterworths, 1981) at 278:

... there is still need to avoid over-extension of the definition of the scope of federal categories of power if balance is to be maintained in our constitution. Complete concurrency of federal powers with provincial ones, coupled with the doctrine of federal paramountcy, would mean the end of a balanced federal system in Canada. The trend to increased concurrency then may have its dangers for the autonomy of the provinces, though so far the main effect of the trend has been to uphold provincial statutes.

104 Henri Brun \& Eugénie Brouillet, "Le partage des pouvoirs en matière d'immigration: une perspective Québécoise", in P. Thibault, B. Pelletier \& L. Perret, eds., Les mélanges Gérald-A. Beaudoin : Les défis du Constitutionnalisme (Cowansville Que.: Éditions Yvon Blais, 2002) 55, at 66. 
strongly federal tendencies in Canadian politics. ${ }^{105}$ In other words, there is a significant gap between the law of Canadian federalism and the sociopolitical governing realities of the nation, a gap that has grown substantially since Wheare published his study.

The quasi-federal elements of the Canadian constitutional text identified by Wheare - such as the federal disallowance and declaratory powers - remain legally unaltered. Attempts to amend the Constitution to repeal or limit some of its quasi-federal aspects failed with the Meech Lake and Charlottetown Accords. The Supreme Court has been unwilling to use the federal principle to constrain the legal scope of the disallowance or declaratory powers. ${ }^{106}$ Instead, the Court has placed its faith in politics to produce governing practices faithful to the federal principle. As La Forest J. wrote regarding the federal government's abandonment of the disallowance power and infrequent resort to the declaratory power:

It was not the courts but political forces that dictated their near demise. ... Their inappropriate use will always raise grave political issues, issues that the provincial authorities and the citizenry would be quick to raise. In a word, protection against abuse of these draconian powers is left to the inchoate but very real and effective political forces that undergird federalism. ${ }^{107}$

Just as the Court has placed its faith in the politics of federalism to prevent abuse of the disallowance and declaratory powers, it may also be confident that expansion of the legal potential for federal dominance resulting from judicial interpretation of the division of powers carries little risk for the federal principle in practice. Federal governments in Canada pay a heavy political price for running roughshod over provincial interests, even though they have a growing legal capacity to do so. In areas of shared jurisdiction, the federal government is much more likely to seek negotiated, mutually satisfactory solutions than it is to impose federal priorities on the provinces. Indeed, even in areas of exclusive federal jurisdiction, the federal government normally gives

105 K.C. Wheare, Federal Government, 4th ed. (London: Oxford University Press, 1963) at 20: “... although the Canadian Constitution is quasi-federal in law, it is predominantly federal in practice. Or, to put it another way, although Canada has not a federal constitution, it has a federal government."

106 See Reference re Power of Disallowance and Reservation, [1938] S.C.R. 71; Ontario Hydro v. Ontario (Labour Relations Board), [1993] S.C.J. No. 99, [1993] 3 S.C.R. 327.

107 Ontario Hydro, id., at 372. 
significant weight to provincial interests. The politics of a balanced and cooperative federalism has prevailed over our quasi-federal constitutional law.

Let me be clear about two points regarding the centralizing possibilities created by the law of Canadian federalism. First of all, it is nothing new. The potential for federal dominance exists in a number of features of the Constitution Act, 1867, most notably in the federal powers of disallowance and reservation. My point is simply that the Court's interpretation of the division of powers has done more to expand the potential for federal dominance than it has to curtail it. Second, the potential for federal dominance created by the constitutional text and the Supreme Court's interpretation of the division of powers has not been realized in contemporary political practice. Canadian provinces are hardly legislatively hamstrung by an overbearing central government. To the contrary, the provinces have expansive jurisdiction over many important areas of social policy, including education, health care and commercial regulation. In contemporary Canadian politics, the provinces complain much less about limits on their legislative jurisdiction than they do about a mismatch between their fiscal resources and the breadth of their legislative responsibilities. In short, the centralizing potential inherent in our constitutional law has long been held in check by the decentralizing political forces present in the federation.

In light of the powerful centrifugal forces at work in Canadian politics, the Supreme Court's tendency to adopt a posture of judicial restraint in federalism cases, and to interpret both federal and provincial heads of power expansively, may be defended as the best approach to democracy and federalism in the Canadian context. The Court's approach maximizes the democratic space available for the exercise of federal and provincial jurisdiction without posing an undue threat to the federal principle in practice. It seems likely that if the political restraints on Parliamentary interference with provincial autonomy were less powerful, the Court might be much more cautious about interpreting federal heads of power as broadly and flexibly as it has.

The risk of the Court's approach to federalism is precisely the degree to which it relies on political bargaining to secure adherence to the federal principle. The political dynamics of Canadian federalism 
may not operate equitably for particular provinces. ${ }^{108}$ They may vary across time or from issue to issue. Even when cooperative federalism is working well, the continuing and growing gap between quasi-federal law and political practices faithful to the federal principle may itself have destabilizing effects for the federation. So long as the provincial pursuit of distinct policies in the growing areas of shared jurisdiction is conditional upon federal consent or forbearance, the provinces cannot be confident that their autonomy will be safeguarded in the future. In these circumstances, should we be surprised by the apparent paradox of Canada being wracked by periodic existential crises despite the many successes of cooperative federalism? Could it be that an important part of the explanation for our continuing constitutional struggles is that the provinces are so frequently cast in the role of supplicants to federal power, negotiating with a legally dominant party for the right to pursue distinct legislative policies?

It is perhaps not possible to be confident about the answers to such questions. But if we take the federal principle seriously, if we value the promotion and preservation of provincial diversity as much as national unity, then there is a strong case for closing the gap between our quasifederal constitutional law and our federal political practices, especially when it can be done without significantly limiting the totality of democratic space available to Parliament and the provincial legislatures. Steps in this direction could include returning to a narrow definition of conflict for the purposes of the federal paramountcy rule; abandoning or significantly reducing resort to the interjurisdictional immunity doctrine to limit the application of provincial statutes; and exercising great caution before allowing federal statutes or conditional federal spending to intrude on areas of exclusive provincial jurisdiction. ${ }^{109}$ The contrary tendencies in the Court's recent case law are cause for concern.

108 For an excellent discussion of the dangers of leaving the determination of the federalprovincial balance of power to political bargaining, see Katherine Swinton, The Supreme Court and Canadian Federalism: The Laskin-Dickson Years (Toronto: Carswell, 1990), at 40-55.

109 For further elaboration of how the Court's interpretation of the division of powers could better respect the federal principle, see Eugénie Brouillet, "La dilution du principe fédératif et la jurisprudence de la Cour suprême du Canada" (2004) 45 Cahiers de Droit 7, at para. 99ff; Ryder, supra, note 94 . 
